\title{
色彩提示に基づく空ガラス透過光の色彩設計および 赤外線制御性能向上を目的とした光学多層膜構造設計
}

\section{Structural Design of the Multilayer Coatings on Windowpane for the Required Sense of Color and the Infrared Radiation Control}

\author{
○学 高橋 史晴・信州大院 \\ Fumiharu TAKAHASHI, \\ Graduate School of Shinshu University
}

\author{
学 滝沢 旬平・信州大院 \\ Junpei TAKIZAWA, \\ Graduate School of Shinshu University
}

\author{
正 中村 正行・信州大学 \\ Masayuki NAKAMURA, \\ Shinshu University
}

Key Words: Optimum Design, Inverse Analysis, Color Design, Chromaticity Diagram, Optical Multilayer Coatings, Windowpane

Windowpane with optical multilayer coatings has ability to control the color and solar energy through the glass. The optical transmittance in the visible region is affected by the interference in the multi-layer coatings. It follows that any color emerges on the scenery through the window. Therefore, it is important to design the color according to the user's own preferences for residential usage. The chromaticity diagram can indicate a specific color by using RGB values in the two-dimensional diagram. This paper reports on the results of design of the multilayer coatings to satisfy the user's sense of the color using the uniform chromaticity scale diagram.

\section{1. はじめに}

住宅において空ガラスは熱の流入出が最大になる部分で ある。太陽からの輻射熱を空ガラスで制御し，冷暖房負荷 の抑制に効果的な省エネルギー仕様の空ガラスが注目され ている.一方で，太陽光エネルギー制御性能を高めるため に空ガラス表面にコーディングを施すと可視光透過スペク トルが変化するため, ガラス越しの風景に自然な状態とは 異なる色彩が現れる。そのため，空ガラスでの太陽光制御 においては，熱線である赤外線制御と透過性を確保するた めの可視光制御を同時に達成する必要がある.

本研究では人の感性に基づいた色彩を示す光学多層膜付 加空ガラスを実現することを目的に, 多層膜構造設計につ いて検討を行ってきた ${ }^{(1)(2)}$. 光学多層膜をコーディングし た空ガラスは，季節ごとの太陽の入射角度の差を利用し， 赤外線は季節を通して制御し, 可視光は望みの色彩を示す ように制御する。制御波長域ごとに目標值を定め, 多層膜 構造を適切に設計することで，選択した色彩を実現する分 光特性を得ることができる.ここでは，色彩の選択にディ スプレイなどの発光色の評価に用いられる $u^{\prime} v^{\prime}$ 均等色度図 を利用して，より感性に近い色彩を実現する方法について 検討する。

\section{2. 色度図による色彩選択}

\section{$2.1 u^{\prime} v^{\prime}$ 均等色度图の利用}

$x y$ 色度図は, 色度図上における距離が物理量である $X Y Z$ 值の差を示すが, それが人の感覚における差とは異なるた め色空間の均等性が保障されておらず，色差を扱うのには 適さない，均等色空間という色差を定量的に扱うための表 色系がFig.1に示す $u^{\prime} v^{\prime}$ 均等色度図であり,この色度図では 色空間が均等になる. 均等色度図は色彩を感覚的に決定す ることに優れており， $u^{\prime} v^{\prime}$ 均等色度図の色を選択すること で，より感性に合った色の色度座標を感覚的に選択するこ とができる. 色度座標 $(x, y)$ から色度座標 $\left(u^{\prime}, v^{\prime}\right)$ への変換 ${ }^{(3)}$ を次に示す.

$$
\left\{\begin{array}{l}
u^{\prime}=\frac{4 x}{-2 x+12 y+3} \\
v^{\prime}=\frac{9 y}{-2 x+12 y+3}
\end{array}\right.
$$

\section{2 分光透過率同定逆解析}

光学多層膜の設計において望みの色彩を実現するために は，色度図によって選択した色彩から設計の目標値となる 可視領域の分光透過率を求める必要がある。望みの色彩に 対忘する三刺激值から逆解析により選択した色彩を示す分 光透過率を同定することが可能である(2). 色度図を用いて 選択した色彩に対寸る三刺激值を用いて，特定の色彩に相 当する分光透過率を導出する問題を最適化問題に䚻着させ て解く.この最適化問題を次に示寸.

(1)制約条件

$0 \leq T(\lambda) \leq 100 \%$

(2)評洒関数

$$
\begin{aligned}
& W=c_{x}\left(\frac{X_{T}-X}{X_{\max }}\right)^{2}+c_{y}\left(\frac{Y_{T}-Y}{Y_{\max }}\right)^{2}+c_{z}\left(\frac{Z_{T}-Z}{Z_{\max }}\right)^{2} \\
& \left\{\begin{array}{l}
X=k \int_{v i s} \bar{x}(\lambda) O(\lambda) T(\lambda) d \lambda \\
Y=k \int_{\text {vis }} \bar{y}(\lambda) O(\lambda) T(\lambda) d \lambda \\
Z=k \int_{\text {vis }} \bar{z}(\lambda) O(\lambda) T(\lambda) d \lambda
\end{array}\right. \\
& k=100 / \int_{\text {vis }} \bar{y}(\lambda) O(\lambda) d \lambda
\end{aligned}
$$

(3)最適化パラメータ $\quad \boldsymbol{P}=\left\{a_{1}, a_{2}, \cdots, a_{m-1}, a_{m}\right\}$

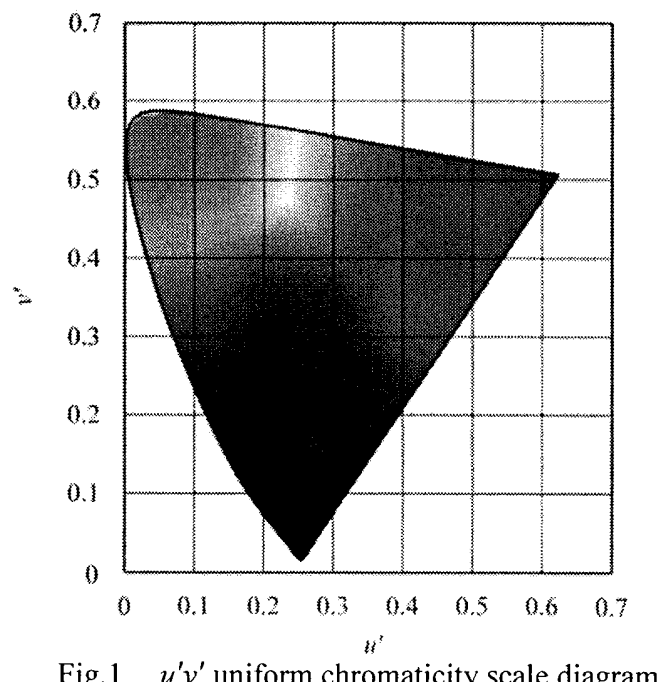

Fig.1 $u^{\prime} v^{\prime}$ uniform chromaticity scale diagram 
ただし，Tは透過率を表わし，次式で与えられる.

$$
T(\lambda)=\frac{1}{M} \sum_{m=0}^{M-1} a_{m} e^{2 \pi i m \lambda / M}
$$

$\lambda$ は波長， $X_{T}, Y_{T}, Z_{T}$ は目標の三刺激值， $X, Y, Z$ は三刺激 值, $X_{\text {max }}, Y_{\text {max }}, Z_{\text {max }}$ は三刺激值の最大值, $\bar{x}, \bar{y}, \bar{z}$ は $\mathrm{CIE}$ 等色関数, $O$ は標準の光 $\mathrm{D}_{65}, c_{x}, c_{y}, c_{z}$ は重み係数, vis は可視光波長， $M$ は可視領域の計算点数を表す，最適化パ ラメータは式(7)の離散逆Fourier変換の係数 $a_{m}$ とし, 係数 $a_{m}$ を決定することにより分光透過率を求める. この最適化問 題では評価関数 $W$ を最小とするようにパラメータの值を求 める.

\section{3. 色彩の再現性の確認}

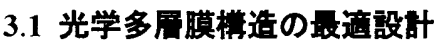

色度図によって選択した色彩がFig.2に示すような多層膜 構造によって実現できるか確認するために，逆解析によっ て得られた分光透過率をもとに多層膜構造の設計を行う. 多層膜の設計には著者の一人が開発した遺伝的アルゴリズ ムを用いた光学多層膜最適設計システムを使用する。これ により，赤外線制御と可視光による色彩の制御が同時に可 能である. 色度図によって得られたRGB值と設計した多層 膜構造のRGB值を比較することによって色彩の再現性を確 認する.

\section{2 設㖕仕㭏}

赤外線領域は780 2000nm，可視光領域は380 780nmとし て設計を行う。目標の色彩は室内から外の景色を見る色彩 であり，色度図から例題として3点選択した．可視領域の 目標值は色度図によって選択した色彩から，最適化パラメ 一夕数を $m=10$ として分光透過率同定逆解析 ${ }^{(2)}$ 上り求め, 目 標值に士5\%の幅を与えた值とする. また，赤外線の目標反 射率は90 100\%とした. 多層膜の分光特性は光の入射角に 依存する. 赤外線は夏季の入射角度を $75 \mathrm{deg}$, 冬季の入射角 度を $35 \mathrm{deg}$ とした．可視光の入射角度は，垂直入射 $0 \mathrm{deg}$ とす る. 基板にコーティングする多層膜の最大層数が 10 層(外側 5層，内側5層)の場合の例について検討する．入射媒質と透 過媒質は空気(屈折率 $N=1.00$ ), 基板には $2 \mathrm{~mm}$ のガラス材 $\operatorname{BK} 7(N=1.52)$ を用い，コーティング材料には $\mathrm{SiO}_{2}(N=1.46)$, $\mathrm{Al}_{2} \mathrm{O}_{3}(N=1.65), \mathrm{Ta}_{2} \mathrm{O}_{5}(N=2.05), \mathrm{TiO}_{2}(N=2.24), \mathrm{ZrO}_{2}(N=2.04)$, $\mathrm{HfO}_{2}(N=1.99), \mathrm{ZnO}_{2}(N=2.16)$ の 種類から2〜3種類を選択す るものと仮定する。また成膜可能な膜厚の範囲は $30.0 \sim 500 \mathrm{~nm}$ とした. 以上の条件より光学多層膜最適設計シ ステムを用いて設計を行った。

\section{3 設計結果}

Fig.3に設計した光学多層膜付加空ガラスの可視光領域の 分光透過率を示す. 空ガラスの分光透過率はほぼ目標值を 満たしているといえる. また, Table 1に色度図によって選 択したRGB值と設計した空ガラスのRGB值の比較を行っ た. Table 1より, どの例題もRGB值の大きさは同傾向であ り, 両者の值の差は小さい, また, 多層膜を施さないガラ スを透過するスペクトルと比較したものをTable 2に示す. 色彩を可視化するプログラム(1)で色彩を確認したところ, 設計した空ガラスは目標と同系統の色彩を示しており, 選 択した色彩を実現すると同時に, 夏と冬の赤外線制御を可 能とする設計結果を得ることができた.

\section{4. おわりに}

本研究では, 人の感性に基づいた色彩を示す光学多層膜 付加空ガラスを実現するために， $u^{\prime} v^{\prime}$ 均等色度図に基づい て同定した可視光の分光透過率を目標値として多層膜構造 を設計した。 その結果, 多層膜構造最適化によって要求さ れた色彩と熱線制御効果をより精度よく達成することがで きた。

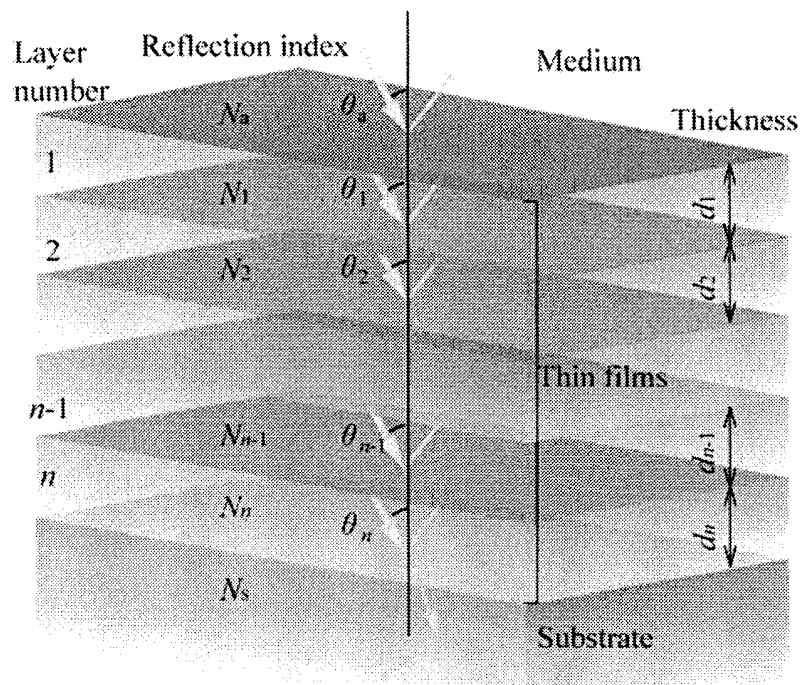

Fig.2 Structure of multi-layer coatings

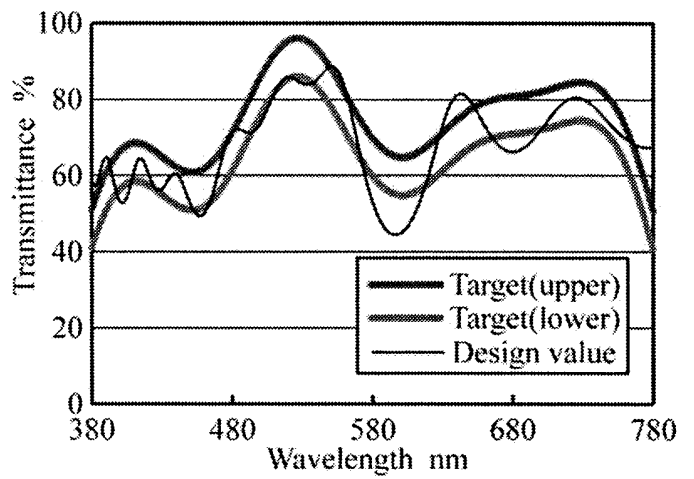

Fig.3 Results of identification of transmittance spectrum for Example 1

Table 1 RGB values

\begin{tabular}{l|c|c}
\hline & $\begin{array}{c}\text { Chromaticity diagram } \\
(\mathrm{R}, \mathrm{G}, \mathrm{B})\end{array}$ & $\begin{array}{c}\text { Design value } \\
(\mathrm{R}, \mathrm{G}, \mathrm{B})\end{array}$ \\
\hline \hline Example 1 & $(200,234,200)$ & $(189,230,198)$ \\
\hline Example 2 & $(215,215,240)$ & $(213,217,237)$ \\
\hline Example 3 & $(255,215,215)$ & $(254,216,216)$ \\
\hline
\end{tabular}

Table 2 Control performance on trancmittance / reflectance \%

\begin{tabular}{l|c|c|c}
\hline & \multicolumn{2}{|c|}{ Infrared region } & Visible region \\
\hline & $\begin{array}{c}\text { Reflectance } \\
\left(\theta_{\text {sum }}=75 \mathrm{deg}\right)\end{array}$ & $\begin{array}{c}\text { Transmittance } \\
\left(\theta_{\text {win }}=35 \mathrm{deg}\right)\end{array}$ & $\begin{array}{c}\text { Transmittance } \\
\left(\theta_{\text {win }}=0 \mathrm{deg}\right)\end{array}$ \\
\hline Example 1 & 51.2 & 68.8 & 68.3 \\
\hline Example 2 & 50.7 & 72.7 & 69.3 \\
\hline Example 3 & 51.1 & 71.3 & 71.9 \\
\hline Float glass & 34.7 & 84.0 & 90.4 \\
\hline
\end{tabular}

\section{参考文献}

（1）上田純平，山村知孝，中村正行，多層膜空ガラスの透 過光に対する色彩解析と感性設計, 第18回設計工学・ システム部門講演会CD-ROM論文集, (2008), pp.225226.

（2）上田純平, 滝沢旬平, 高橋史晴, 中村正行, 色度図上 逆解析を用いた光学多層膜付加空ガラスの色彩選択, 第19回設計工学・システム部門講演会CD-ROM論文 集, No.09-6, (2009), pp.507-508.

（3）日本色彩学会, 色彩科学ハンドブック(第2版), 東京大 学出版会, (1998), p.123. 